\title{
Régiók hálózata és gazdasági teljesítmény A régiók közötti tudáshálózati struktúra makrogazdasági szerepének vizsgálata
}

\author{
Network of regions and economic performance \\ - an analysis of the macroeconomic impact of \\ the structure of interregional knowledge networks
}

\author{
SEBESTYÉN TAMÁS
}

KULCSSZAVAK: tudáshálózatok, szabadalmi kooperáció, hálózatelemzés

\begin{abstract}
ABSZTRAKT: A gazdasági növekedéssel foglalkozó irodalom a tudásfelhalmozás szerepét hangsúlyozza, az új tudás keletkezése és terjedése azonban nem független azoktól a hálózatoktól, amelyek a gazdaság szereplőit kötik össze. A hálózatelméleti irodalom a valós hálózatok két fő jellemzőjét, a "kis világ” jelleget (rövid elérési utak szorosan kapcsolt lokális csoportokkal) és a skálafüggetlenséget (a kapcsolati számok aszimmetrikus eloszlása) hangsúlyozza, kiemelve, hogy a hálózat makrostruktúrája a hálózati rendszer teljesítményét befolyásolja. Jelen tanulmányban az† vizsgálom, hogy milyen összefüggés mutatható ki a szabadalmi együttmúködési hálózatok struktúrája, valamint a gazdasági teljesítmény között. Együttmúködési hálózatokon NUTS 3 régiók közötti kapcsolatrendszereket értünk, és e kapcsolatrendszerek országos szintű struktúráját vizsgáljuk. A vizsgálat 27 európai országra terjed ki, az eredmények az† mutatják, hogy a régiók hálózatban vett átlagos közelsége, valamint a domináns centrális régiók jelenléte pozitív kapcsolatban áll a gazdasági teljesítménnyel.
\end{abstract}

KEYWORDS: knowledge networks, patent co-inventorship, network analysis

ABSTRACT: Literature on economic growth emphasizes the importance of knowledge accumulation in long term development. However, regarding both its generation and diffusion, knowledge is not independent of the network structures interconnecting the individual actors of the economy. Theoretical and empirical studies of networks have shown that the structure of networks is an important determining factor of the aggregate performance of these networks. First, the notion of 'small world' networks was coined emphasizing that real-life networks retain local cohesion while 'bridging ties' contribute to short paths into the network. Further empirical evidence showed that these networks show asymmetric degree distributions with few central actors and many peripheral ones. These macro structures are shown to affect the performance of networks. However, there is no study which examines the effect of the structure, through which the spatial units of a country are linked together, on aggregate economic outcome. This specific aspect is examined in this study where network

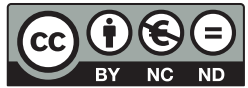


structure is regarded as the map of knowledge flows between NUTS3 statistical regions of the EU. We introduce the methodological basis for the analysis of network structure and use this methodology in order to analyse the relationship between the intranational knowledge network structure and economic output of the $27 \mathrm{EU}$ countries. The networks refer to interregional patent innovator networks which were identified using OECD patent statistics. This method gives our study a regional perspective. Our results suggest that higher levels of proximity among regions and more pronounced scale-free properties (centre-periphery structure) contribute to a higher level of economic output per capita. This indicates that interpersonal proximity as well as strong knowledge centres are important building blocks for an efficient system of interregional knowledge flows.

\section{Bevezetés}

Az utóbbi időben az innovációval foglalkozó szakirodalom kiemelt figyelemmel fordult a hálózati struktúrák tanulmányozása felé. Ez az érdeklődés részben onnan származik, hogy a személyes kapcsolatok szerepe a tudástranszferben nyilvánvalóvá vált, másrészt viszont a hálózatelemzési módszertan az elméleti fizika és a szociológia irányából ösztönözte az innovációval foglalkozó szakembereket a kutatások ilyen irányú kiterjesztésére.

A gazdasági növekedéssel foglalkozó szerzők hamar felismerték, hogy a hosszú távú növekedés kulcsa a technológiai fejlődés, vagy más szemszögből nézve a tudás felhalmozása (példaként: Solow 1957, Romer 1990, Grosman, Helpman 1991, Aghion, Howitt 1992). A felismerés logikusan vezetett el az innováció diffúziójának és a gazdasági növekedés lokalitásának kérdéseihez. Breschi és Lissoni (2003) e két kérdés vonatkozásában kiemeli, hogy az innováció terjedésében a kutatók személyes kapcsolathálója kiemelt szerepet játszik, a személyes kapcsolatok alakulásának tipikusan lokális jellege pedig hozzájárul ahhoz, hogy az innováció terjedése bizonyos térbeli korlátokat mutat.

A személyes kapcsolathálók szintje felett egy tágabb perspektívát ad a kérdésnek a regionális innovációs rendszerek irodalma: e szerint a megközelítés szerint egy térség innovációs kapacitását nagy részben az intézményi feltételek és az egyes innovációs szereplők (vállalatok, egyetemek, kutatóhelyek, kormányzati szervek) közötti viszonyrendszer befolyásolja (Cooke 2001, Cooke és szerzőtársai 1997). Természetesen ez nem jelenti, hogy ezek a viszonyrendszerek nem a személyes kapcsolatokon alapulnak, a megközelítés azonban rámutat a kapcsolatrendszerek többdimenziós jellegére. Hasonló gondolatokat vet fel a nemzeti innovációs rendszerek irodalma, csak itt a regionális szint helyett a nemzeti innovációs intézményrendszer szerepe kerül az előtérbe (Lundvall 1992). Egy érdekes, az eddigiekből fakadó további felvetés - amelyre e tanulmány próbál reflektálni -, hogy a nemzeti szinten megfigyelt innovációs potenciál a regionális rendszerek összekapcsolódásából adódik, így a régiók közötti viszonyrend- 
szerek is lényeges szerepet játszhatnak az innovációban és ezáltal a gazdasági növekedésben.

Az innovációval és tudásáramlással foglalkozó szakirodalomban találunk néhány példát arra, hogy régiók közötti kapcsolati hálók struktúráját vizsgálják, ezek a tanulmányok azonban nem kapcsolják össze a struktúra kérdését a gazdasági teljesítménnyel. Maggioni és Uberti (2006) öt európai ország régióit vizsgálja, Ejermo és Karlsson (2004) pedig svéd régiók közötti kapcsolati hálókat vizsgálnak, szabadalmi együttműködésekre alapozva. Megállapításaik szerint a földrajzi távolság szerepe továbbra is jelentős meghatározója a régiók közötti tudásáramlásnak. Maggioni és szerzőtársai (2011) olasz tartományok között vizsgálják a tudásáramlást, a szabadalmak feltalálóit, a tudás forrásaiként, bejelentőit pedig a tudás felhasználóiként kezelve. Eredményeik elsősorban a szabadalmi bejelentők nagyobb koncentráltságát mutatják, a specifikus hálózati struktúra és a gazdasági teljesítmény közötti kapcsolatot azonban nem vizsgálják.

Az előbb röviden felvázolt innovációs irányvonal mellett a tanulmány másik fontos motivációs forrása a hálózatelmélet, egészen specifikusan a hálózati struktúra és a hálózatra épülő rendszer teljesítménye közötti összefüggés. A hálózatok és hálózati struktúra első modellje az Erdős és Rényi által bevezetett véletlen hálózat volt (Erdős, Rényi 1959). Véletlen hálózatról akkor beszélünk, amikor a hálózat csomópontjai közötti kapcsolatok (élek) véletlenszerűen, különösebb speciális struktúra nélkül rendeződnek el. Később elsősorban szociológiai vizsgálatok mutattak rá, hogy a társadalmi hálózatok nem adhatók vissza teljes mértékben az Erdős-Rényi-féle véletlen hálózatok modelljével. Ezek a vizsgálatok a társadalmi hálózatokat úgynevezett „kis világokként” írják le, ahol szorosan összefüggő (összekapcsolt) lokális csoportokat áthidaló kapcsolatok kötnek össze. Az elnevezés arra utal, hogy ezekben a hálózatokban a csomópontok közötti átlagos elérési úthossz relatíve kicsi, miközben a lokális csoportok megőrzik viszonylag éles határvonalaikat (Travers, Milgram 1969, Granovetter 1973, Barabási 2002). A „kis világok” intuitív elképzelését később Watts és Strogatz (1998) formalizálták.

Barabási (2002) azt emeli ki, hogy a valós hálózatoknak a „kis világ” jellegen kívül egy további fontos empirikus tulajdonságuk van a véletlen hálózatokkal szemben, nevezetesen, hogy a fokszámok (kapcsolati számok) eloszlása a csomópontok között erősen aszimmetrikus: néhány csomópont rendkívül nagy számú kapcsolattal rendelkezik, míg a csomópontok többsége kevés kapcsolattal bír. Ezt a speciális struktúrát skálafüggetlen hálózatnak nevezzük. ${ }^{1}$ Barabási és munkatársai több publikációban azt a fontos felismerést mutatták be, hogy a valóságban előforduló hálózatok (közlekedési hálózatok, társadalmi kapcsolathálók, publikációs hálózatok, kristályszerkezetek, fehérjehálózatok stb.) számottevő része ilyen skálafüggetlen tulajdonságot mutat (Barabási, Albert 1999, Barabási et al. 2000, Barabási 2002). Barabási és Albert (1999) egy egyszerű modellt is felvázolnak, amely a skálafüggetlenség kialakulását magyarázza. 
Az előbbiekben több olyan sarkalatos hálózati struktúrát ismertettem, amelyeket a tanulmányban vizsgálni fogok (véletlen hálózatok, kis világok, skálafüggetlen struktúra). E struktúrák mérésének lehetőségeit a 3. részben mutatom be. Fontos azonban azt is kiemelni, hogy a hálózati struktúra pusztán deskriptív jellegén felül a hálózatelmélet jelentős szerepet tulajdonít a hálózati struktúra és a hálózatra épülő rendszer teljesítménye közötti kapcsolatnak. Cowan és Jonard (2004), valamint Cowan (2005) például megmutatják, hogy a véletlen és szabályos hálózatok között található köztes, „kis világ” struktúrát mutató szerkezetek előnyösek a tudás keletkezése és terjedése szempontjából. Csermely (2005) pedig számos, az élet különböző területeiről citált hálózati példán mutatja meg, hogy a skálafüggetlen struktúrák előnyös evolúciós tulajdonságokat mutatnak, ezáltal egyfajta optimális struktúrának tekinthetők.

Az elmondottakból tehát jól látszik az innovációval foglalkozó szakirodalom azon tendenciája, amely a tudáshálózatok szerepének felismerése irányába mutat, ugyanakkor a hálózatelmélet azon vonulata is, amely a hálózat struktúrájának és a hálózat (vagy a hálózatra épülő más rendszer) teljesítményének, outputjának viszonyát igyekszik feltárni. Az innovációval foglalkozó kutatások a hálózati kapcsolatokat tekintve elsősorban a tudáshálózatokon keresztül zajló tudástranszfer jellemzőit, a hálózatok struktúráját vizsgálják. Érdekes kérdés lehet ugyanakkor az is, hogy e hálózatok strukturális jellemzői miként befolyásolják a hálózatokra épülő gazdaság teljesítményét. Jelen tanulmány a hálózati struktúra és a gazdasági teljesítmény közötti összefüggést próbálja empirikus eszközökkel megragadni, figyelembe véve a korábban említett, regionális szintű innovációs rendszerek közötti kapcsolatok szerepét. Így az elemzés lehatárolása két szinten történik: egyfelől a vizsgálat tárgyát országok, nemzetgazdaságok és azok teljesítménye képezi, másrészt viszont az országokon belüli tudáshálózatok struktúráját úgy közelítem meg, hogy a kapcsolati hálók csomópontjait régiók képezik. Így tehát azt vizsgálom, hogy az országok régióit egymással összekötő tudáshálózati struktúra és az országok gazdasági teljesítménye között milyen összefüggés található.

A dolgozat felépítése a következő. A második szakasz alaposabb áttekintését adja az imént bemutatott hálózati struktúráknak és a struktúrák kvantifikálása során alkalmazott mutatóknak. A harmadik szakaszban bemutatom a felhasznált adatokat, különös tekintettel az általam összeállított hálózati adatbázisra. A negyedik szakaszban ismertetem az elemzés ökonometriai hátterét és az eredményeket, végül egy rövid összefoglalást adok a dolgozat főbb megállapításairól.

\section{Hálózati modellek és mutatók}

Mivel a tanulmányban a hálózati struktúrák szerepét elemzem, röviden kit kell térnem azokra az eszközökre, amelyek segítségével egy hálózat strukturális jel- 
lemzői megragadhatók. Mindenekelőtt fontos megjegyezni, hogy egy hálózat leírható egy úgynevezett kapcsolati mátrix segítségével, amelyben a sorok és oszlopok száma megegyezik a csomópontok számával, a mátrix elemei pedig a csomópontok közötti kapcsolatokat reprezentálják. Ezek az elemek lehetnek kétértéküek (alkalmasan 0 és 1), ha csupán a kapcsolatok meglétére vagy hiányára utalnak, de bármilyen valós értéket felvehetnek, ha a kapcsolatok súlyát, erősségét is figyelembe vesszük. A továbbiakban a kétértékű mátrixot A-val, a súlyozott mátrixot $R$-rel jelölöm.

A hálózatelmélet (gráfelmélet) eleinte úgy tekintett a valós hálózatokra, mint véletlen hálózatokra (Barabási, 2002), vagyis olyan struktúrákra, ahol a hálózat csomópontjai közötti kapcsolatok előfordulási valószínűsége egyenletes. Ezen a vonalon Erdős és Rényi (1959) munkáját követően a véletlen hálózatoknak széles irodalma alakult ki (Bollobás 2001). Többen is felvetették azonban, hogy a valós hálózatok nem feltétlenül írhatók le a véletlen hálózatok logikájával, hanem a hálózati kapcsolatok speciális szerveződési rendet követnek. Granovetter $(1973,1983)$ arra hívja fel a figyelmet, hogy a társadalmi hálózatok szorosan integrált lokális csoportok halmazaként írhatók le, ahol a lokális csoportokon belül „erős” kapcsolatok felelősek a kohézióért, ugyanakkor a hálózat egészének nagyon fontos elemei a lokális csoportokat összeköto” "gyenge" kapcsolatok. Ez a különbségtétel a társadalmi tőke irodalmában is megjelenik: itt kohéziós (bonding) és áthidaló (bridging) kapcsolatoknak nevezik őket (pl. Callois, Angeon 2004). ${ }^{2}$

A hálózati struktúra két mutatója segítségével a fenti jelenségek könnyen értelmezhetők. Az első ilyen mutató az átlagos elérési út hossza a hálózatban. Ha adott a hálózatot leíró kapcsolati mátrix, akkor ennek segítségével megadható a hálózat tagjainak geodetikus (azaz a hálózatban vett) távolságát leíró $\mathbf{D}=\left[d_{i j}\right]$ mátrix, ahol a mátrix $d_{i j}$ általános eleme az $i$ és $j$ csomópontok között a hálózatban vett legrövidebb utat jelenti. ${ }^{3} \mathrm{Az}$ átlagos elérési út ebből a hálózat tagjai közötti legrövidebb utak átlagaként adódik:

$$
a d=\frac{\sum_{i=1}^{N} \sum_{j=1}^{N} d_{i j}}{N(N-1)}
$$

A második hálózati mutató az úgynevezett klaszterezettségi mutató, amely a hálózat tagjainak lokális környezetét leíró mutatószámnak tekinthető. Cowan (2005) meghatározása szerint a klaszterezettség annak mutatójaként értelmezhető, hogy egy adott csomópont szomszédai milyen mértékben szomszédai egymásnak is, vagy más szavakkal, hogy egy-egy csomópont környezete mennyire szorosan integrált. A kapcsolati mátrix elemeit felhasználva a klaszterezettség az alábbi összefüggés alapján számítható ki: 
(2)

$$
c_{i}=\frac{\sum_{k=1}^{N} a_{i k} \sum_{j=1}^{N} a_{i j} a_{k j}}{N_{i}\left(N_{i}-1\right)},
$$

ahol $N_{i}=\sum_{j} a_{i j}$, azaz az i-edik csomópont szomszédainak száma, $a_{i j}$ pedig a kapcsolati mátrix általános eleme. A fenti lokális klaszterezettségi mutatóból egyszerü átlagolással egy olyan strukturális mutatót kapunk, amely a hálózat lokális struktúráját (a lokális kapcsolatok relevanciáját) globális szinten képes megragadni:

$$
a c=\frac{\sum_{i=1}^{N} c_{i}}{N}
$$

Belátható, hogy egy véletlen hálózatban a klaszterezettség alacsony szintü, ugyanakkor a véletlenszerüség okán a hálózat tagjai közötti elérési utak relatíve rövidek lesznek. A véletlen hálózatokat tehát rövid elérési utak és alacsony átlagos klaszterezettség jellemzi. Ezzel szemben a Granovetter-féle hálózatokat magas klaszterezettség jellemzi, éppen a sürü lokális kapcsolatok miatt, ugyanakkor az elérési utak rövidek maradnak, mivel a lokális csoportokat összekötő „gyenge” kapcsolatok a hálózat távoli (eltérő lokális csoportokhoz tartozó) tagjai között is gyors kommunikációt biztosítanak (lásd pl. Watts, Strogatz 1998, Cowan 2005). Ahogyan korábban jeleztem, azt a speciális tulajdonságot, hogy a hálózati struktúrát magas szintü klaszterezettség és rövid elérési utak együttes jelenléte jellemzi, a hálózatelmélet és a szociológiai irodalom kis világnak nevezi.

Barabási (2002) a valós hálózatok egy további fontos jellemzőjére hívja fel a figyelmet: arra, hogy az empirikusan megfigyelt hálózatokban a kapcsolati számok (fokszámok) eloszlása rendszerint aszimmetrikus. Néhány súlyponti szereplőnek nagyon sok kapcsolata van, míg a többségnek lényegesen kevesebb. A bevezetőben ismertetett megfontolások alapján ezt a jelenséget skálafüggetlenségnek nevezzük. Barabási és Albert (1999) kimutatják, hogy az ilyen skálafüggetlen hálózatok esetén a fokszámeloszlás (legalábbis annak vége) egy egyszerü hatványfüggvénnyel leírható:

$$
z=k s^{-\delta}
$$

ahol $s$ a fokszámértékeket jelöli, $z$ egy adott fokszám előfordulásának valószínűsége, $k$ és $\delta$ pedig az eloszlás paraméterei. A $\delta$ paraméter értéke kiemelten fontos, mivel ez jellemzi a skálafüggetlenség mértékét: magas $\delta$ érték esetén a fokszámeloszlást leíró függvény görbülete nagyobb, míg alacsonyabb $\delta$ érték esetén a görbület kisebb. ${ }^{4}$ Ezek alapján a (4) eloszlásfüggvény $\delta$ paramétere alkalmas mércéje lehet a skálafüggetlenségnek egy hálózatban. $\delta$ alacsonyabb ér- 
tékeire a fokszámeloszlás egyre egyenletesebbé válik, $\delta=0$ esetén pedig az eloszlás egyenletes. ${ }^{5}$ Egy adott hálózat esetén a fokszámértékek relatív gyakorisága meghatározható, és ezekre a relatív gyakorisági értékekre egyszerű statisztikai módszerekkel illeszthető egy, a (4) egyenletnek megfelelő függvény, így $\delta$ értéke adott hálózati struktúrára meghatározható.

\section{Az adatbázis leírása}

Az elemzés elvégzéséhez értelemszerüen kétféle adattípusra van szükségünk. Egyfelől a régiók közötti tudásáramlást leíró hálózati kapcsolatokat kell feltárnunk, hogy az előző szakaszban ismertetett kapcsolati mátrixok meghatározhatóak legyenek, másrészt pedig a gazdasági teljesítmény tekintetében kell információval rendelkeznünk. Az alábbiakban bemutatom a felhasznált két féle adatforrást, különös figyelemmel a hálózati adatok felépítésére.

\section{Makrogazdasági adatok}

A gazdasági teljesítményt leíró adatbázis kérdése meglehetősen egyszerü, mivel ezek az adatok többnyire rendelkezésre állnak más forrásokból. Esetünkben a Pennsylvaniai Egyetem által publikált és rendszeresen frissített, a világ országainak makrogazdasági adatait tartalmazó PENN World Table adatbázis szolgál a gazdasági teljesítményt leíró adatbázis forrásául (Heston et al. 2009). Az adatbázisból mindössze két adatsort használunk fel: a reál GDP egy főre jutó értékének idősorait a vizsgálatunk tárgyát képező országokra, valamint ebből egyszerủen számítható módon az egy főre jutó reál GDP növekedési ütemét.

\section{Hálózati adatbázis}

A hálózati struktúra vizsgálatához a gazdasági teljesítménnyel szemben nem állnak rendelkezésre kész adatok, így egy ilyen adatbázist más adatforrásokra támaszkodva tudunk létrehozni. A szakirodalomban elterjedt a szabadalmi hivatkozások használata, mivel ezek a tudás terjedésének nyomait jelentik (Karki 1997, Oppenheim 2000, Chakrabarti et al. 1993, Chen, Hicks 2004, Singh 2003). Néhány kutatás a szabadalmi hivatkozások segítségével hálózatokat vizsgál, azaz a hivatkozások alapján épít fel kapcsolati hálózatokat (Gress 2010, Li et al. 2007). Ejermo és Karlsson (2004) azt írják, hogy a szabadalmi hivatkozások használatával kapcsolatos problémák miatt a szabadalmak feltalálói közötti kapcsolatokat érdemes vizsgálni, mivel ezek a hivatkozásokhoz képest a tudástranszfer robosztusabb közelítő változóját jelentik. Szabadalmi együttműködé- 
sen alapuló hálózatokat vizsgálnak továbbá Maggioni és Uberti (2006) valamint Maggioni és szerzőtársai (2010). A szabadalmi adatbázisok használatának elönyeiről és hátrányairól Griliches (1990) ad összefoglalót.

Jelen tanulmányban a tudáshálózatokat régiók között építem fel, azaz a hálózat csomópontjai régiók lesznek, a hálózat élei pedig a régiók közötti tudásáramlás intenzitását reprezentálják. A tudásáramlás intenzitását szabadalmi feltalálói együttműködés alapján határozom meg, azaz két régió között akkor tételezek fel kapcsolatot, ha a két régió feltalálói valamely szabadalom kapcsán együttműködtek. Minél több ilyen együttműködés figyelhető meg a régiók között, annál magasabb kapcsolati intenzitást feltételezek.

A szabadalmi adatok az OECD által publikált regionális szabadalmi adatbázisból származnak (REGPAT adatbázis, OECD 2009), amely a feltalálók címei alapján az egyes szabadalmakhoz régiókat rendel. Ez a regionális bontás NUTS 3 szinten áll rendelkezésre. Az adatbázis felépítésének részleteit egy tavalyi írásom (Sebestyén 2011) tartalmazza. A kapott hálózat természetesen súlyozott, hiszen a régiók közötti együttmúködés eseteinek száma változhat. A kapcsolatok intenzitását az egyes régiókhoz tartozó feltalálók által jegyzett közös szabadalmak száma alapján határozom meg.

Az 1. ábra egy egyszerü példát mutat a feltalálók szabadalmi együttműködésére. Három régió (R1, R2 és R3) hét feltalálója (I1, ..., I7) két szabadalmon dolgozik együtt (a sötéttel és a világossal jelölt személyek egy-egy szabadalom feltalálói), és feltesszük, hogy az egyes szabadalmak feltalálói közötti kapcsolati háló teljes (maximális sűrűségü). ${ }^{6}$ A feltalálók közötti személyes kapcsolatokat jelölik a szaggatott vonalak. Az ábra jobb oldalán lévő blokkban látható a régiók

\section{1. ábra: Egy példa szabadalmi feltalálói együttmúködési hálózatok felépítésére An example for constructing patent coinventorship networks}
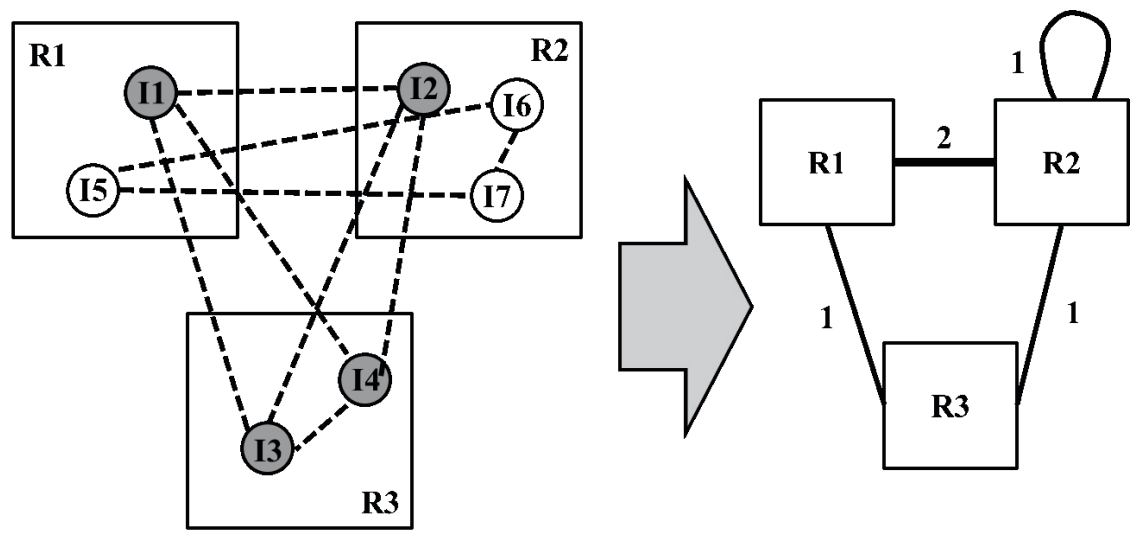

Forrás: saját szerkesztés. 
közötti hálózat, amit a fenti információk alapján állítottam össze. A kapcsolat súlya két régió között 1-es, ha a két régió feltalálói egy szabadalomban működtek együtt, míg 2-es, ha két szabadalom esetén történt kooperáció. Az is látható, hogy az így létrejövő hálózat hurkokat is tartalmazhat, vagyis figyelembe vehetjük a régión belüli tudásáramlás volumenét is. Bár a rendelkezésre álló adatbázis tartalmazza ezt az információt, a lehetőséget a tanulmányban nem használom ki. ${ }^{7}$

Fontos kiegészítés a fentiekhez az az eset, amikor egy feltaláló több szabadalom létrehozásában is részt vesz. Ezt a helyzetet speciálisan úgy lehetne kezelni, ha a szabadalmak feltalálóihoz is külön, egyedi azonosítót rendelnénk. A felhasznált adatbázis azonban csak szöveges és nem standardizált formában tartalmazza a feltalálók neveit, így azok tisztítása, kiváltképpen az általam kezelt milliós rekordszámnál, nagyon jelentős vállalkozás lenne. Ennek köszönhetően az 1. ábra jobb paneljéhez hasonló struktúrát kapunk abban az esetben is, ha adott esetben két feltaláló azonos (például I2 és I6 ugyanaz a személy). Ennek torzító hatása egyetlen esetben tűnhet problematikusnak, nevezetesen, amikor a feltaláló lakhelyet változtat. Esetünkben azonban ez nem feltétlenül jelent érdemi torzítást, mivel a lakhelyváltoztatás értelemszerủen régiók közötti tudásáramlást jelent, igaz nem abban az interperszonális értelemben, mint amire a hálózati adatok felépítésének módszertanát építettem.

Egyrészt annak érdekében, hogy az elemzés kezelhető keretek között maradjon, másrészt pedig az adatfeldolgozás során felmerülő számítástechnikai kapacitáskorlátok okán, az elemzést első körben a 27 európai uniós tagországra végeztem el. Ez összesen 1330 NUTS 3 szintű régiót jelent. A nyers adatbázis így egy olyan kapcsolati mátrix, amely 1330 sorral és oszloppal rendelkezik. Ahogy azonban azt a bevezetőben kiemeltem, a tanulmány célja az, hogy a régiók közötti tudáshálózatok szerveződési struktúrája és a gazdasági teljesítmény közötti kapcsolatot országos szinten vizsgáljam. Így az 1330 régiót tartalmazó hálózatot az egyes országoknak megfelelő részhálózatokra bontom, és az országhatárokon átívelő kapcsolatokat nem vizsgálom. Ez a szűkítés természetesen fontos információkat hagy figyelmen kívül, azonban tanulmányom fókusza miatt céljaimmal konzisztens, hiszen az országok gazdasági teljesítménye, valamint az országot alkotó régiókat összekötő tudáshálózati struktúra közötti kapcsolatot kívánom vizsgálni. ${ }^{8}$

Módszertani szempontból ez azt jelenti, hogy az 1330 csomópontra (régióra) felírt $R$ kapcsolati mátrixot 27 kisebb kapcsolati mátrixra bontom, amelyek egyenként csupán egy adott ország régióit, mint csomópontokat tartalmazzák. Fontos még hozzátennem, hogy ezek az adatok az 1981 és 2002 közötti időszakra állnak rendelkezésre. Annak érdekében, hogy a szabadalmi feltalálói tevékenység időtávja és a szabadalmi bejelentés, mint adatfelvételi egység pontszerű időbelisége közötti diszkrepanciát áthidaljuk, 4 éves időablakokkal dolgozom, azaz egy adott évben feljegyzett szabadalmi bejelentés együttműködési kapcsolatait a három megelőzo évre is „elszámolom”. 


\section{Néhány módszertani megjegyzés}

Az előzőekben bemutatott hálózati adatbázis (kapcsolati mátrixok sora) alkalmas arra, hogy a második szakaszban kifejtett hálózati mutatószámok ezek alapján empirikus oldalról meghatározhatók legyenek, ugyanakkor néhány további módszertani megjegyzést kell tennem.

Először is, a tanulmányban használt klaszterezettségi mutató kétértékű kapcsolati mátrixok esetén alkalmazható. Mivel az adatbázis közvetlenül súlyozott kapcsolati mátrixokat tartalmaz, ezeket kétértékűvé kell tenni. Ez a korrekció meglehetősen egyszerűen elvégezhető: egyes értékeket kapnak azok a cellák, ahol pozitív szám áll, és zérust a többi. Az átlagos elérési úthossz esetén a súlyozott hálózati kapcsolatok értelmezhetők: egy nagyobb súlyszám általában rövidebb elérési utat takar, míg egy alacsonyabb érték hosszabbat. Mivel azonban a klaszterezettség és az átlagos elérési út hossza vizsgálatomnak ugyanabban a dimenziójában jelentkezik mint releváns hálózati mutató (a „kis világok" detektálásánál), ezért a konzisztencia érdekében az átlagos úthossz kiszámításánál is a kétértékủ kapcsolati mátrixokat használom fel. Más a helyzet azonban a skálafüggetlenséget mérő hálózati mutató esetén. Ebben az esetben mind a bináris, mind a súlyozott kapcsolati mátrix alkalmazható, különösebb megszorítások nélkül. ${ }^{9}$

A második módszertani megjegyzés a kapcsolat nélküli csomópontokra vonatkozik. Mind az elérési útnál, mind a klaszterezettségnél problémát jelenthet, ha a hálózatba beleveszem azokat a csomópontokat is, amelyek nem rendelkeznek kapcsolattal: ezek a csomópontok az elérési utat végtelenné teszik, a klaszterezettséget pedig irreálisan csökkentik. Éppen ezért fontos, hogy a számomra releváns, vagyis az összekapcsolt hálózatokon végezzem el az elemzést, figyelmen kívül hagyva a kapcsolat nélküli régiókat.

Harmadszor pedig arra kell felhívnom a figyelmet, hogy miután a fenti három mutatót (átlagos klaszterezettség, átlagos elérési úthossz, skálafüggetlenségi mutató) a hálózati adatok alapján meghatároztam, azok közvetlenül nem összehasonlíthatóak. Ennek oka, hogy az egyes hálózatok mérete az országok között és időben is változik, ${ }^{10}$ továbbá a hálózatok sűrüsége is változik (tipikusan az figyelhető meg, hogy a sűrűség növekszik, a régiók egyre intenzívebben kooperálnak a szabadalmak tekintetében). Éppen ezért szükséges valamilyen viszonyítási alapot bevezetnem, amely révén az egyes országok különböző időszakokban vett hálózati struktúrái összehasonlíthatók. Ez a viszonyítási alap a hálózati szakirodalomban elterjedten alkalmazott módszertan szerint valamilyen referenciahálózat hasonló mutatója.

A klaszterezettség és az elérési út esetében az adott országra az adott idöszakban (évben) érvényes hálózati méret (csomópontszám) és átlagos fokszám segítségével egy véletlen hálózatot hozok létre, amely ugyanekkora mérettel és átlagos fokszámmal rendelkezik. Ennek a referenciahálózatnak kiszámítom a klaszterezettségi mutatóját, valamint az átlagos elérési utat, és az általam meg- 
figyelt empirikus értéket ehhez a referenciaértékhez viszonyítom. Így egy összehasonlítható mutatót kapok, amely e két érték esetében azt jelöli, hogy az általam megfigyelt hálózat klaszterezettsége és átlagos elérési úthossza hogyan viszonyul egy azonos méretű és sűrüségű véletlen hálózat klaszterezettségéhez és átlagos elérési úthosszához.

A skálafüggetlenség esetén hasonló eljárást alkalmazok, itt azonban a viszonyítási alapot nem a véletlen hálózat, hanem egy szélsőségesen skálafüggetlen hálózat képezi. A viszonyítási alapul szolgáló szimulált skálafüggetlen hálózat felépítéséhez egy egyszerű hálózati modellt veszek alapul, amelyet Barabási és Albert (1999) mutatnak be. ${ }^{11}$

\section{Az empirikus modell és eredményei}

Az eddigieket összefoglalva tehát az a célom, hogy az országok belső, régiókat összekötő tudáshálójának struktúrája és a gazdasági teljesítmény közötti kapcsolatot empirikus módszerekkel vizsgáljam. A hálózati struktúrát a gazdaság térbeli egységei, jelen esetben NUTS 3 régiók között felírt hálózatok alapján térképezem fel. A hálózati csomópontok így térbeli egységek, a hálózati kapcsolatok pedig a régiók közötti tudásáramlást reprezentáló szabadalmi kooperációk. Így tehát interregionális tudáshálózatok struktúráját kötöm a gazdasági teljesítményt országos szinten mérő egyszerü mutatószámokhoz.

A második szakaszban a hálózati struktúrát számszerüsítő mutatószámok bevezetésére került sor, ezek alapján két dimenzió mentén összesen négy mutatószám segítségével értelmezhetjük a hálózati struktúrát: a klaszterezettség és az elérési úthossz a „kis világok” szerepét, míg a súlyozott és a súlyozatlan skálafüggetlenségi mutató a skálafüggetlenség szerepét tárhatja fel. A „kis világ” jelleg vizsgálata arra deríthet fényt, hogy a régiók hálózatban vett közelsége (átlagos távolság, elérési út), illetve a hálózat „fürtösödése”, klaszterezettsége milyen mértékben releváns a hálózat teljesítményének meghatározásában, a skálafüggetlenség pedig a hálózat centrális (központi szereplők által dominált) jellegére utal. A bemutatott adatbázist és az abból meghatározott hálózati mutatószámokat felhasználva egyszerű panelregressziós vizsgálatot végzek. A vizsgálat idődimenziója összesen 22 évet ölel fel, 1981-től 2002-ig, és 27 ország adatait tartalmazza (az Európai Unió tagállamainak adatait).

Függő változóként először a reál GDP egy főre jutó értékét veszem figyelembe. Azért van szükség az egy före jutó GDP használatára a teljes GDP-vel szemben, hogy a népességszám és ezáltal az egyes országok méretének hatását kiszűrjem a regresszióból. Ez azért is fontos, mivel a vizsgált hálózati mutatók függetlenek a hálózat méretétől (ezt a célt szolgálja az előző szakasz végén bemutatott referenciapontok alkalmazása), így az elemzés a struktúra és a gazdasági teljesítmény közötti összefüggést alkalmasabban képes megjeleníteni. 
A független változók között, ahogy már említettem, a második szakaszban ismertetett négy mutatót használom fel. Először is a klaszterezettség mutatóját $\left(C L S_{i t}\right)$, ami az $i$ ország $t$ évben kiszámolt klaszterezettségi mutatója, egy azonos méretü, azonos átlagos fokszámú véletlen hálózat klaszterezettségi mutatójához viszonyítva. Így tehát azt méri, hogy a vizsgált hálózati struktúrára milyen mértékben jellemzőek a szorosan kapcsolt csoportok. Másodszor hasonló relatív mutatót képezek az átlagos úthossz tekintetében $\left(P A T H_{i t}\right)$, amely a hálózat csomópontjainak egymástól vett átlagos távolságát mutatja, egyfajta hálózati közelséget mérve ezzel. A harmadik és negyedik mutató a skálafüggetlenséget méri, egyrészt bináris kapcsolati hálózat alapján $\left(S C A L E_{i i t}\right)$, másrészt pedig súlyozott kapcsolati hálózat alapján $\left(S C A L E_{-} W_{i t}\right)$ számolva. Utóbbi két mutató arra alkalmas, hogy a hálózatban jelen lévő centralitás mértékét megragadja. Mivel a vizsgált jelenség szempontjából nem tekinthetek el a hálózati struktúra és a gazdasági teljesítmény közötti kapcsolat időbeliségétől, a magyarázó- és magyarázott változók között különböző léptékű késleltetéseket veszek figyelembe a késleltetés nélküli esettől az ötéves késleltetésig. Mindezt figyelembe véve összesen hatszor négy panelregressziós vizsgálatot végzek el a véletlen koefficiensek módszerét felhasználva, amelyek az alábbi általános formát öltik:

$$
\ln \left(G D P_{i, t}\right)=\beta_{0}+\beta_{1} \times \ln \left(N E T_{i, t-\tau}\right)+v_{i}+\varepsilon_{i, t}
$$

$\mathrm{Az}$ (5) egyenletben a $N E T_{i t}$ változó helyére a fenti négy hálózati mutató valamelyikét helyettesíthetjük. Az esetleges késleltetési hatások figyelembevételét teszi lehetővé, jelzi a $\tau$ index a jobb oldalon. A késleltetéses vizsgálatokat 5 periódusig (évig) végzem el, így $\tau$ értéke 0 -tól 5 -ig terjed. Az 1. táblázat mutatja a vizsgált hatszor négy regresszió főbb eredményeit. Az oszlopok a különböző (0-tól 6 évesig) késleltetéseknek megfelelő regressziókat tartalmazzák, a sorok pedig az egyes hálózati mutatók szerint csoportosítják az eredményeket. Minden esetben a regressziós konstanst és a vizsgált hálózati mutató regressziós együtthatóját tüntetem fel. A regressziók részletes eredményeit a függelék táblázatai tartalmazzák.

A kapott eredmények azt mutatják, hogy a késleltetés nélküli esetben a klaszterezettség, valamint az átlagos elérési úthossz negatív, szignifikáns kapcsolatban áll a kibocsátással. Egészen pontosan ez a következőt jelenti. A klaszterezettségi együttható esetében a magasabb klaszterezettség egyértelműen alacsonyabb kibocsátási szinttel társul, az alacsony klaszterezettség pedig magas kibocsátással. A hálózati struktúra és a hálózati mutatók kapcsán kiemelt összefüggések alapján ez azt jelenti, hogy tipikusan azon hálózatok esetén figyelhetünk meg magasabb kibocsátási szintet, amelyek közelebb állnak a véletlen hálózatokhoz, vagy másképpen, amelyekre a szorosan kapcsolt helyi csoportok kevésbé jellemzőek. A szignifikáns, negatív irányú kapcsolat fennmarad a késleltetéses modellek esetén is, sőt, azt látjuk, hogy a klaszterezettségi együttható koefficiense a 4 és 5 éves késleltetés esetén a legmagasabb, bár a különbség nem 
1. táblázat: A panelregressziós vizsgálatok főbb eredményei Main results of panel regressions

\begin{tabular}{|c|c|c|c|}
\hline & $\operatorname{lag0}$ & $\operatorname{lag} 1$ & lag2 \\
\hline const & $9,75017^{* * *}$ & $9,75473 * * *$ & $9,76146 * * *$ \\
\hline log_CLS & $-0,1621^{* * *}$ & $-0,1516^{* * *}$ & $-0,1463^{\star \star \star}$ \\
\hline const & $9,63206^{* * *}$ & $9,64216^{* * *}$ & $9,65274 * * *$ \\
\hline log_PATH & $-0,2001 * *$ & $-0,1302$ & $-0,1125$ \\
\hline const & $9,72868^{* * *}$ & $9,73675^{* * *}$ & $9,74799 * * *$ \\
\hline log_SCALE & 0,0045 & 0,00476 & 0,00292 \\
\hline const & $9,43744 * * *$ & $9,50164 * * *$ & $9,51685^{* * *}$ \\
\hline log_SCALE_W & $0,11601^{* \star *}$ & $0,10138^{* * *}$ & $0,10071^{* \star *}$ \\
\hline
\end{tabular}

\begin{tabular}{llll}
\hline & \multicolumn{1}{c}{ lag3 } & \multicolumn{1}{c}{ lag4 } & \multicolumn{1}{c}{ lag5 } \\
\hline Const & $9,81143^{* * *}$ & $9,84278^{* * *}$ & $9,84278^{* * *}$ \\
log_CLS & $-0,1692^{* * *}$ & $-0,2043^{* * *}$ & $-0,2043^{* * *}$ \\
\hline const & $9,66467^{* * *}$ & $9,67602^{* * *}$ & $9,68736^{* * *}$ \\
log_PATH & $-0,1066^{* * *}$ & $-0,0735^{* * *}$ & $-0,0074^{* * *}$ \\
\hline Const & $9,76283^{* *}$ & $9,77485^{* *}$ & $9,78773^{* *}$ \\
log_SCALE & $-0,0039^{* * *}$ & $-0,0038^{* * *}$ & $-0,0003^{* * *}$ \\
\hline Const & $9,55489^{* *}$ & $9,56344^{* *}$ & $9,57995^{* *}$ \\
log_SCALE_W & $0,08953^{* *}$ & $0,09482^{* * *}$ & $0,09639^{* * *}$ \\
\hline
\end{tabular}

Megjegyzés: A csillagok száma a szignifikancia-szinteket jelöli: *: 10\%, **: 5\%, ***: 1\%. A változók nevének magyarázatát lásd a táblázat fölötti szövegben!

The number of asterisks stand for the significance level: *: $10 \%,{ }^{* \star}: 5 \%,{ }^{* \star *}: 1 \%$.

Forrás: saját számítás.

tekinthető különösebben jelentősnek. További késleltetések vizsgálata során kiderül, hogy a klaszterezettség együtthatója 4-7 éves késleltetéseknél éri el a legmagasabb abszolút értéket.

Az átlagos elérési út esetén szintén negatív összefüggést találunk: azokban az esetekben, amikor az átlagos elérési út hosszabb, tipikusan alacsony kibocsátást figyelhetünk meg, illetve fordítva, a rövidebb elérési utak magasabb kibocsátással járnak együtt. Akárcsak a klaszterezettségi mutató esetén, most is az a következtetés vonható le, hogy a magasabb kibocsátási szint azon hálózatokra jellemző, amelyek közelebb állnak a véletlenszerű hálózati struktúrához, vagyis rövidebb elérési utakkal rendelkeznek. Ez tehát azt jelenti, hogy minél közelebb vannak egymáshoz átlagosan a hálózat csomópontjai (a közelséget a hálózatban, nem pedig térben értelmezve), annál magasabb kibocsátás figyelhető meg. Ugyanakkor fontos azt is kiemelnem, hogy a vizsgálat során csak a késleltetés nélküli modellnél kaptam szignifikáns negatív eredményt. A koefficiens negatív előjele mindvégig megmarad, bár abszolút értéke egyre kisebb. További vizsgálatok során kiderül, hogy 7-9 éves késleltetés esetén az átlagos elérési út pozitív szignifikáns kapcsolatban áll a kibocsátással, vagyis az előbb leírt negatív hatás megfordul.

Az utóbbi eredmény érdekes következtetésekre vezet. Egy adott időszakban akkor figyelhetünk meg magasabb kibocsátást egy ország esetén, ha a hálózati struktúra jóval korábbi időszakokban hosszabb elérési utakkal jellemezheto", 
a jelenben pedig rövidebb elérési utakkal. Ez a jelenség arra utalhat, hogy a tudás felhalmozásának és felhasználásának szakaszai elválnak egymástól abban az értelemben, hogy különböző hálózati struktúrák kedvezőek az egyes fázisokban. A tudás kezdeti felhalmozásához a lokálisan sűrű, relatíve hosszú elérési utakkal jellemezhető hálózat kedvező, majd később, a tudás terjedése szempontjából a rövid elérési utak válnak fontossá. A kibocsátásban ez olyan módon jelenik meg, hogy a korai, lokálisan sűrü struktúrák katalizálják az új tudás létrehozását, amely aztán a magasabb kibocsátási szintek tudásbázisául szolgál a későbbiekben. A már létrejött tudásbázis azonban úgy tudja kifejteni kedvező hatását, ha a hálózati struktúra áthidaló kapcsolatok kialakításával a tudásdiffúziót felgyorsítja. Azt is meg kell azonban említenem, hogy ezt az elgondolást a klaszterezettségre kapott eredmények önmagukban nem tudják megerősíteni, mivel ott a hosszú késleltetések mellett is a kisebb klaszterezettség kapcsolódik össze a magasabb kibocsátási szinttel.

A skálafüggetlenség vizsgálata során kapott eredmények esetén egyértelműen látszik a súlyozott és a kétértékű hálózat alapján számolt mutatók közötti különbség is. Amennyiben a skálafüggetlenséget a bináris kapcsolati mátrix alapján határozzuk meg, úgy nem kapunk szignifikáns összefüggést a skálafüggetlenség foka és a kibocsátás között. Ha azonban a súlyozott kapcsolati mátrixot vesszük kiindulópontul, vagyis a fokszámeloszlás felírásánál a kapcsolatok intenzitását is figyelembe vesszük, nem csupán a kapcsolatok létezését, úgy az látható, hogy a skálafüggetlenség pozitív szignifikáns kapcsolatban áll a kibocsátással. Egészen pontosan azt találjuk, hogy a magasabb kibocsátás együtt jár a skálafüggetlenségi mutató magasabb értékeivel, ez utóbbi pedig a hálózat fokszámeloszlását leíró hatványfüggvény kitevőjének felel meg. ${ }^{12} \mathrm{Ez}$ tehát azt jelenti, hogy tipikusan azon országok esetén figyelhetünk meg magasabb kibocsátási szintet, ahol a régiók közötti tudáshálózatok erős centrális struktúrát mutatnak: néhány kiemelkedő régió dominálja a hálózat struktúráját, míg a régiók nagyobbik része marginálisabb szereplő. A késleltetést tartalmazó eseteket vizsgálva azt tapasztaljuk, hogy a pozitív szignifikáns hatás mindvégig megmarad, az együtthatók értéke azonban csökken.

Ez az eredmény látszólag ellentmondásban áll a klaszterezettségre és az átlagos elérési úthosszra kapott eredményekkel: ott ugyanis azt láttuk, hogy a véletlenszerü hálózati struktúra felé történő elmozdulás kapcsolódik össze a magasabb kibocsátással, most viszont éppen azt látjuk, hogy a skálafüggetlenség növekedése, azaz a struktúra speciális szabályok szerinti szerveződése is pozitív hatással van a kibocsátásra. Fontos kiemelni, hogy ez az ellentmondás csak látszólagos, ugyanis a skálafüggetlen hálózatok tipikusan rövid elérési utakkal jellemezhetők, így az átlagos elérési úthossz kapcsán adódó eredmény egybevág a skálafüggetlenségre kapott összefüggésekkel. A klaszterezettségi mutató értéke ugyanakkor nincsen szoros kapcsolatban a skálafüggetlenséggel: skálafüggetlen hálózatok lehetnek erősebben és gyengébben klaszterezettek, bár az igaz, hogy minél szélsőségesebben skálafüggetlen egy hálózat, a klaszte- 
rezettség annál kisebb. Így a kapott eredmények arra mutatnak, hogy azok a hálózati struktúrák adják a legkedvezőbb alapot a magasabb gazdasági teljesítményhez, amelyek egyszerre jellemezhetők magas centralitással és alacsony szintű klaszterezettséggel.

Hasonló elemzéseket végeztem úgy is, hogy eredményváltozóként nem a GDP szintjét, hanem a GDP éves növekedési ütemét szerepeltettem az (5) egyenlet jobb oldalán. Ezekre a regressziókra nem kaptam szignifikáns koefficienseket, leszámítva az 5 éves késleltetést, ahol a klaszterezettség esetében enyhén szignifikáns negatív, az átlagos elérési úthossz esetében pedig enyhén szignifikáns pozitív együttható adódik. A regressziós eredmények közlésétől, azok marginális relevanciája miatt, eltekintek.

Mindezek alapján megállapítható, hogy a hálózati struktúra és a gazdasági teljesítmény között létezik szignifikáns kapcsolat: az, hogy egy gazdaság térbeli egységeit milyen struktúrában füzik össze tudásáramlási kapcsolatok, befolyásolja, hogy a gazdaság egésze milyen makroszintű teljesítményt nyújt. Érdekes ugyanakkor kitérnünk a bevezetőben és a hálózati mutatók alfejezetben már tárgyalt két hálózati modellel kapcsolatos érvelések és a most prezentált empirikus eredmények közötti összefüggésekre. Elsősorban a „kis világ” struktúrával kapcsolatos gondolatokat emelném ki. Több tanulmány is rámutat (Cowan 2005, Cowan et al. 2006), hogy a „kis világok” hatékony hálózati struktúrának tekinthetők, mivel egyszerre biztosítják a lokális kohéziót (a magas klaszterezettség révén) és a gyors diffúziót (a rövid elérési utak okán). Az általam kapott eredmények ugyanakkor részben ellentmondanak ennek a képnek: azt látjuk, hogy azok a hálózati struktúrák kapcsolódnak a magasabb kibocsátási szinthez, amelyek kevésbé a lokális struktúrákra, mint inkább a gyors elérési utakra épülnek - itt is fel kell azonban hívni a figyelmet a közelség és a teljesítmény időben változó szerepére.

Természetesen az eredmények nem engednek teljes rálátást a hálózati struktúra és a rá épülő rendszer teljesítménye közötti összefüggésekre, csupán a struktúrát leíró néhány mutató és a teljesítmény együttmozgását figyelhetjük meg. A klaszterezettségi mutató és az átlagos elérési út esetén feltárt negatív kapcsolat takarhat egy olyan folyamatot is, amely a szabályos, vagyis magas klaszterezettségű és hosszú elérési utakkal jellemezhető hálózati struktúra irányából a „kis világok” felé történő elmozdulást jelent. Ez az elmozdulás ugyanis mind a klaszterezettség, mind az átlagos elérési úthossz csökkenésével jár. A „kis világok” jelentősége éppen abban áll, hogy a két mutató csökkenésének üteme eltérő, így található olyan tartomány, ahol a hálózat lokális struktúrái fennmaradnak, az átlagos elérési úthossz azonban már jelentősen lerövidül. Így az általam kapott eredmények tükrözhetik ezt a folyamatot is, amely során egy lokálisan erősen strukturált hálózat felől a „kis világokra” jellemző struktúrák irányába mozdul el a hálózati struktúra.

A skálafüggetlenség kapcsán egy további érdekes implikációt emelek ki. Amint a bevezetőben említettem, a hálózati struktúrával kapcsolatos empirikus 
kutatások azt tárták fel, hogy a valóságban megfigyelhető hálózatok jelentős része skálafüggetlen tulajdonságokkal rendelkezik. Barabási (2002) úgy érvel, hogy ez a speciális struktúra a komplex rendszerek egyik fontos szerveződési elve lehet. Ez felveti a gondolatot, hogy egyfajta evolúciós fejlődés során a komplex rendszerek struktúrája a skálafüggetlen struktúra felé mozdul, mivel ez a struktúra nagyfokú hatékonyságot biztosít a rendszer aggregált teljesítménye szempontjából. Empirikus eredményeim érdekes adalékkal szolgálnak ebben a tekintetben: azt látjuk, hogy a skálafüggetlen hálózati struktúrák valóban magasabb kibocsátással társulnak, így egy első megerősítést nyerhetünk arra a hipotézisre vonatkozóan, hogy a valóságban megfigyelt hálózati struktúrák azért mutatják a skálafüggetlenség jellemzőit, mivel ez a struktúra a rendszer egészének teljesítménye szempontjából kiemelkedően hatékony.

Ez a következtetés ugyanakkor a rendszer teljesítménye és elemeinek egyenlőtlensége közötti trade-off kapcsolatra világít rá. A rendszer elemei esetünkben a régiók, a teljesítményt pedig gazdasági értelemben mérjük. Két fontos megállapításom, miszerint a gazdasági teljesítmény a régiók közötti hálózatok véletlenszerűségével és skálafüggetlenségével párhuzamosan növekszik, egyben azt is jelenti, hogy a magasabb kibocsátás a régiók közötti egyenlőtlenségek növekedésével jár. Ez a jelenség a hálózati struktúra változásából fakad: a véletlenszerủ hálózatban a hálózati kapcsolatok számának szóródása nagyobb, mint az ellenpólusként szolgáló szabályos hálózatban, és a skálafüggetlen hálózatban is nagyobb ez a szóródás a véletlen hálózathoz képest. ${ }^{13}$ Azzal a feltevéssel, hogy a nagyobb számú külső kapcsolat a hozzáférhető tudás bővítésén keresztül nagyobb gazdasági teljesítményhez vezet, a pusztán hálózati értelemben vett egyenlőtlenséget akár gazdasági dimenzióba is áthelyezhetjük. Érvelésem tehát azt támasztja alá, hogy a magasabb teljesítményt mutató hálózati struktúrák egyben magasabb belső egyenlőtlenséggel is jellemezhetők.

Az előző gondolatot visszacsatolva a skálafüggetlen hálózatok stabilitása kapcsán elmondottakhoz, azt a hipotézist fogalmazhatjuk meg, hogy a skálafüggetlen hálózatok belső egyenlőtlenségei éppen a sokféleség erősítése révén biztosítják azt a belső kohéziót, amely a rendszer egészének magas hatékonyságát eredményezi. Így tehát egyfajta dinamikus kapcsolatot látunk kibontakozni a sokféleség (vagy másképpen egyenlőtlenség), illetve az aggergált teljesítmény között, ahol a két folyamat egymást erősíti.

\section{Összefoglalás}

A tanulmányban arra tettem kísérletet, hogy megvizsgáljak két, eddig eltérő keretek közt tárgyalt, de gondolatilag összetartozó jelenség közötti összefüggést. A gazdasági növekedéssel foglalkozó szakirodalom a tudás felhalmozásának jelentőségét emeli ki, a tudás azonban sem keletkezésében, sem 
terjedésében nem független azoktól a hálózatoktól és hálózati struktúráktól, amelyek a gazdaság egyedi szereplőit, egységeit összekötik, és az információ, valamint az innováció áramlását biztosítják.

A gazdasági teljesítmény és a hálózati struktúrák közötti összefüggés empirikus vizsgálatát végeztem el, a fókuszt hangsúlyozottan az utóbbi tényezőre helyezve. Bemutattam azokat a módszertani és statisztikai eszközöket, amelyek egyrészt az interregionális tudáshálózatok (szabadalmi együttmüködésen alapuló) feltérképezését teszik lehetővé, másrészt pedig az így kapott empirikus hálózati struktúrák elemzéséhez szükségesek. Ezt követően a gazdasági teljesítmény és a hálózati struktúrát leíró mutatók közötti kapcsolat elemzését végeztem el, relatíve hosszú időszakra vonatkozóan.

A kapott eredmények pozitívnak mondhatók, amennyiben a véletlenszerüség és a skálafüggetlenség esetében egyaránt sikerült kapcsolatot kimutatni a gazdasági teljesítmény és a hálózati mutatószámok között. Két dimenzió mentén vizsgálva a hálózati struktúrák szerepét, azt állapítottam meg, hogy a véletlenszerüség és a skálafüggetlenség növekedése pozitív kapcsolatban áll a gazdasági teljesítménnyel. Ez azt jelenti, hogy a régiók közötti együttműködés akkor járul hozzá nagyobb mértékben a gazdasági teljesítményhez, amikor ezek a kapcsolatok véletlenszerủen, egymástól távolabb eső régiókat is összekapcsolnak, vagyis kevésbé jellemző a hálózatokra az erős, bezáródó lokális csoportosulás, illetve, amikor a centrumok erőforrás-akkumuláló hatását a periferikusabb régiók ki képesek használni. Így tehát azt a következtetést fogalmazhatom meg, hogy egyrészt a periferikus és centrális régiók közötti kooperáció erősítése, másrészt pedig a periferikus régiók közötti kooperáció támogatása olyan célja lehet a fejlesztéspolitikának, ami a regionális szempontok mellett a gazdaság egészének szintjén is pozitív hozadékkal bír.

A vizsgálatnak ez a része azonban további megfontolásokat is igényel. A kapott pozitív eredmények ellenére nem világos, hogy a megfigyelt kapcsolat a hálózati struktúra és a gazdasági teljesítmény tekintetében milyen mértékben vezethető vissza az elméleti megfontolások kapcsán tárgyalt összefüggésekre. Minthogy az alkalmazott módszertan csupán a kapcsolat létezését igazolja, egyáltalán nem lehetünk biztosak abban, hogy ennek a kapcsolatnak mi az iránya. Az elmélet ugyan sugallja, hogy a hálózati struktúra felől a gazdasági teljesítmény irányába mutat a kapcsolat, ugyanakkor a fordítottja is könnyen elképzelhető: a gazdasági tevékenység változása (fejlődése) vezetett a megfigyelt strukturális változásokhoz. Ugyanakkor az is elképzelhető, hogy mindössze álkorrelációról van szó, vagyis a gazdasági teljesítmény és a hálózati struktúra változásait valamilyen külső, jelen esetben exogénnek tekinthető tényező befolyásolja, különösen azért, mert a megfigyelt hálózati kapcsolatok maguk is olyan jellegüek, amelyek a gazdasági vagy a társadalmi környezet változásaira hosszabb távon reagálhatnak.

A dolgozatban bemutatott kutatási eredmények természetesen sok szempontból további kiegészítéseket igényelnek. Egyfelől az alkalmazott ökonometriai módszertan finomítható, másrészt pedig a gazdasági teljesítményt magyarázó to- 
vábbi mutatószámok bevonására kerülhet sor. A módszertani szempontok mellett egy további érdekes elméleti kiegészítés lehet a tárgyalt folyamatok közötti visszacsatolások elemzése. A téma tárgyalása során érvelésem a hálózati struktúrának a gazdasági teljesítményre gyakorolt hatását hangsúlyozta. Nem tekinthetünk el azonban attól, hogy a kapcsolat a két jelenség között nem hierarchikus. A gazdasági teljesítmény alakulása is hatással lehet a hálózati struktúra dinamikájára - az itt bemutatott eredmények akár a jelenségnek ezt a vetületét is szemléltethetik, mivel oksági kapcsolatot nem állítottam fel a megfigyelt jelenségek között.

A témakör e szélesebb kontextusba helyezése fontos adalékokkal szolgálhat a korábban kiemelt gondolati hipotézisre vonatkozóan is, nevezetesen, hogy a skálafüggetlen hálózati struktúrák dominanciája mennyiben köthető e struktúrák magasabb hatékonyságához.

\section{Jegyzetek}

1 Az elnevezés abból fakad, hogy ezek a hálózatok nem írhatók le egy átlagos fokszámmal (reprezentatív szereplővel), vagyis a fokszámeloszlásnak nincsen egy jól meghatározható átlaga, skálája.

2 A társadalmi tôke irodalmában e két kapcsolattípus közötti különbségnek lényeges szerepet tulajdonítanak: az erős lokális (bonding) kapcsolatok biztosítják a társadalmi csoportok kohézióját, míg a gyenge, globális (bridging) kapcsolatok teszik lehetővé a csoportok közötti kommunikációt, az újdonságok, az innovációk áramlását, így pedig a lokális csoportok elszigetelődésének, adott esetben önmagába záródásának (lock-in) esélyét csökkentik.

3 A D mátrix a gráfelméletből ismert „legrövidebb út” algoritmusok segítségével így könnyen meghatározható, bár a kapcsolati mátrix segítségével zárt forma nem írható fel rá.

4 A függvény görbülete arra utal, hogy az eloszlás mennyire szélsőséges: minél nagyobb a görbület, annál kevesebb a „köztes” fokszám, azaz a relatíve sok kapcsolattal rendelkező csomópontok száma kevesebb, míg a relatíve kevés kapcsolattal rendelkezők száma egyre több lesz.

5 Természetesen ez az „egyenletesség” nem feltétlenül értendő szó szerint: 0 értéket kaphatunk akkor is, ha a hálózat valamennyi tagjának pontosan azonos számú kapcsolata van, de akkor is, ha a fokszámeloszlás szimmetrikus (például a véletlen hálózatok esetén adódó Poisson-eloszlás). Ennek a különbségnek természetesen nagy jelentősége nincsen, mivel a kapott hálózat mindkét esetben nem skálafüggetlen, a különbség csupán annyi, hogy az ebben az esetben jól definiálható átlagos fokszám körül a fokszámeloszlásnak mekkora a szóródása.

6 Természetesen elképzelhető, hogy a szabadalom feltalálói is speciális hálózati struktúrába rendeződnek, erre vonatkozóan azonban a rendelkezésre álló adatok nem biztosítanak információt. Ugyanakkor a feltalálók között teljes (maximális sűrűségü) hálózat feltételezése nem feltétlenül jelent lényeges torzítást, annál is inkább, mivel egy szabadalomhoz tipikusan kisszámú feltaláló tartozik, így a teljes kapcsolati háló feltételezése nem állhat nagyon messze a valóságtól (a speciális struktúra feltevése jellemzően nagyobb feltalálói létszám esetén lenne releváns).

7 A régiókon belüli kapcsolati intenzitást is felhasználó elemzést közölnek Sebestyén és szerzőtársai (2011).

8 Ezen túlmenően ismét hivatkozom Maggioni és Uberti (2006) megállapítására, miszerint a feltalálói kapcsolatok jellemzően országhatárokon belül dominálnak, így az internacionális kapcsolatok kiiktatása nem jelent lényeges információveszteséget. A jelen tanulmányban használt adatbázisból kitűnik, hogy az országhatárokon átívelő kapcsolatok aránya az összes kapcsolaton belül súlyozott kapcsolatokkal számolva 3\%-ról 10\%-ra növekszik a vizsgált időszakban, bi- 
náris kapcsolatokkal számolva pedig 10\% körüli szintről 30\% körüli szintre. Ez azt mutatja, hogy bár az országhatárokon átnyúló szabadalmi feltalálói kapcsolatok szerepe növekszik, az összes ilyen kapcsolathoz képest még mindig csak marginális szerepet játszanak. Természetesen egy további érdekes vizsgálat lehet e kapcsolatok specifikus szerepének elemzése.

Kiderül azonban, hogy a súlyozott kapcsolati mátrix esetében a skálafüggetlenség jelenléte sokkal inkább érzékelhető, míg a bináris mátrix esetén kevésbé. Ennek egyértelmű oka, hogy a súlyozott mátrix esetén a centrális csomópontok jelenléte nyilvánvaló, míg ezek a centrális elemek eltűnhetnek, vagy dominanciájuk csökkenhet, ha a nagyszámú kapcsolatot egy másik csomópont felé egyetlen kapcsolati egységgé redukáljuk. Ezenfelül a súlyozott hálózatok esetén kapott mutatók megfelelnek annak az általános képnek, amelyet más hálózatok esetén is feltártak, nevezetesen, hogy a skálafüggetlenséget jellemző hatványfüggvény kitevőjének értéke tipikusan -2 és -3 között található (Barabási 2002). Ezzel szemben a bináris mátrix alkalmazása esetén ezek az értékek a lényegesen alacsonyabb szintű skálafüggetlenséget mutató -1 és 0 közötti tartományba esnek.

10 Természetesen nem lesz több vagy kevesebb régió, viszont az előző megjegyzésem alapján belátható, hogy előfordulhat olyan eset, amikor egy korábban kívülálló régió bekerül a hálózatba, vagy pedig egy korábban a hálózatban lévő régió elveszíti kapcsolatait.

11 Fontos azt is kiemelni, hogy a véletlenszerűség hatásának kiszűrése végett a viszonyítási alapunk nem egyetlen szimulált véletlen vagy skálafüggetlen hálózat megfelelő mutatója, hanem 100 (adott méretre és átlagos fokszámra elvégzett) szimuláció után az egyenként kiszámolt hálózati mutatók átlaga jelenti a referenciapontot.

12 Fontos kiemelni, hogy a pozitív irányú kapcsolat azért jelenti a 3. fejezet modelljében talált pozitív kapcsolat alátámasztását, mert az empirikus vizsgálatban általam használt $S C A L E_{i t}$ és $S C A L E_{-} W_{i t}$ relatív mutatók, amelyekben a ténylegesen megfigyelt kitevőket egy hipotetikus, szélsőségesen skálafüggetlen hálózatban adódó kitevőhöz viszonyítjuk. Minthogy mind a megfigyelt hálózatok ilyen értékei, mind a hipotetikus hálózatok kitevői negatívak (a skálafüggetlenség okán), így eredményül pozitív számot kapunk. Minél nagyobb ez a pozitív szám, annál nagyobb a megfigyelt hálózat kitevője a hipotetikus hálózat kitevőjéhez képest, következésképpen annál inkább skálafüggetlen a megfigyelt hálózat.

13 Ez utóbbi megállapítás azon alapul, hogy a skálafüggetlenség növekedésével a struktúra olyan irányba mozdul el, ami néhány domináns szereplő és sok marginális szereplő halmazát jelenti. 


\section{Függelék}

F1. táblázat: Részletes regressziós eredmények a klaszterezettség mint magyarázóváltozó esetén

Detailed panel regression results int he csase of clustering as independent variable

\begin{tabular}{l|rrrrrr}
\hline \multicolumn{1}{c|}{ log_CLS lag0 } & \multicolumn{1}{c}{ lag1 } & \multicolumn{1}{c}{ lag2 } & \multicolumn{1}{c}{ lag3 } & \multicolumn{1}{c}{ lag4 } & \multicolumn{1}{c}{ lag5 } \\
\hline Constant & 9,7502 & 9,7547 & 9,7615 & 9,8114 & 9,8428 & 9,8428 \\
Constant standard error & 0,0984 & 0,0977 & 0,1009 & 0,1026 & 0,1019 & 0,1019 \\
Constant t-ratio & 99,0495 & 99,8327 & 96,7597 & 95,6682 & 96,5641 & 96,5641 \\
Constant p-value & $<0,00001$ & $<0,00001$ & $<0,00001$ & $<0,00001$ & $<0,00001$ & $<0,00001$ \\
Regressor & $-0,1621$ & $-0,1516$ & $-0,1463$ & $-0,1692$ & $-0,2043$ & $-0,2043$ \\
Regressor standard error & 0,0298 & 0,0309 & 0,0314 & 0,0316 & 0,0320 & 0,0320 \\
Regressor t-ratio & $-5,4354$ & $-4,9050$ & $-4,6565$ & $-5,3521$ & $-6,3903$ & $-6,3903$ \\
Regressor p-value & $<0,00001$ & $<0,00001$ & $<0,00001$ & $<0,00001$ & $<0,00001$ & $<0,00001$ \\
Mean dependent var & 9,7608 & 9,7737 & 9,7889 & 9,8047 & 9,8184 & 9,8184 \\
Sum squared resid & 90,7977 & 85,6360 & 80,2377 & 73,5544 & 70,3217 & 70,3217 \\
Log-likelihood & $-273,849$ & $-258,701$ & $-242,841$ & $-224,055$ & $-213,589$ & $-213,589$ \\
Schwarz criterion & 559,7641 & 529,3638 & 497,5303 & 459,8431 & 438,7938 & 438,7938 \\
S. D. dependent var & 0,4549 & 0,4509 & 0,4461 & 0,4410 & 0,4372 & 0,4372 \\
S. E. of regression & 0,4672 & 0,4656 & 0,4638 & 0,4571 & 0,4602 & 0,4602 \\
Akaike criterion & 551,6979 & 521,4009 & 489,6818 & 452,1101 & 431,1776 & 431,1776 \\
Hannan-Quinn & 554,8869 & 524,5556 & 492,7980 & 455,1872 & 434,2146 & 434,2146 \\
\hline
\end{tabular}

Forrás: saját számítás.

F2. táblázat: Részletes regressziós eredmények az átlagos elérési úthossz mint magyarázóváltozó esetén

Detailed panel regression results in the case of average path length as independent variable

\begin{tabular}{l|rrrrrr}
\hline \multicolumn{1}{c|}{ log_PATH } & \multicolumn{1}{c}{ lag0 } & \multicolumn{1}{c}{ lagl } & \multicolumn{1}{c}{ lag2 } & \multicolumn{1}{c}{ lag3 } & \multicolumn{1}{c}{ lag4 } & \multicolumn{1}{c}{ lag5 } \\
\hline Constant & 9,6321 & 9,6422 & 9,6527 & 9,6647 & 9,6760 & 9,6874 \\
Constant standard error & 0,0882 & 0,0912 & 0,0923 & 0,0939 & 0,0956 & 0,0964 \\
Constant t-ratio & 109,1945 & 105,6906 & 104,5575 & 102,9673 & 101,1740 & 100,4438 \\
Constant p-value & $<0,00001$ & $<0,00001$ & $<0,00001$ & $<0,00001$ & $<0,00001$ & $<0,00001$ \\
Regressor & $-0,2001$ & $-0,1302$ & $-0,1125$ & $-0,1066$ & $-0,0735$ & $-0,0074$ \\
Regressor standard error & 0,0923 & 0,0917 & 0,0897 & 0,0880 & 0,0874 & 0,0839 \\
Regressor t-ratio & $-2,1679$ & $-1,4195$ & $-1,2542$ & $-1,2121$ & $-0,8417$ & $-0,0876$ \\
Regressor p-value & 0,0307 & 0,1565 & 0,2105 & 0,2262 & 0,4005 & 0,9302 \\
Mean dependent var & 9,6956 & 9,7045 & 9,7142 & 9,7264 & 9,7380 & 9,7516 \\
Sum squared resid & 114,5047 & 108,7023 & 103,3804 & 97,6933 & 92,2233 & 86,1749 \\
Log-likelihood & $-334,194$ & $-317,823$ & $-302,431$ & $-286,286$ & $-270,584$ & $-253,467$ \\
Schwarz criterion & 680,6757 & 647,8411 & 616,9606 & 584,5694 & 553,0587 & 518,7068 \\
S. D. dependent var & 0,4871 & 0,4878 & 0,4880 & 0,4869 & 0,4867 & 0,4856 \\
S. E. of regression & 0,4962 & 0,4948 & 0,4944 & 0,4930 & 0,4920 & 0,4899 \\
Akaike criterion & 672,3873 & 639,6450 & 608,8611 & 576,5715 & 545,1678 & 510,9346 \\
Hannan-Quinn & 675,6493 & 642,8769 & 612,0612 & 579,7379 & 548,2983 & 514,0250 \\
\hline
\end{tabular}

Forrás: saját számítás. 
F3. táblázat: Részletes regressziós eredmények a súlyozatlan hálózati kapcsolatok alapján számolt skálafüggetlenségi mutató mint magyarázóváltozó esetén

Detailed panel regression results in the case of scalefree exponent calculated from binary network

\begin{tabular}{l|rrrrrr}
\hline \multicolumn{1}{c|}{ log_SCALE } & \multicolumn{1}{c}{ lag0 } & \multicolumn{1}{c}{ lag1 } & \multicolumn{1}{c}{ lag2 } & \multicolumn{1}{c}{ lag3 } & \multicolumn{1}{c}{ lag4 } & \multicolumn{1}{c}{ lag5 } \\
\hline Constant & 9,7287 & 9,7368 & 9,7480 & 9,7628 & 9,7749 & 9,7877 \\
Constant standard error & 0,0963 & 0,0971 & 0,0973 & 0,0965 & 0,0955 & 0,0930 \\
Constant t-ratio & 101,0298 & 100,3167 & 100,2277 & 101,1451 & 102,3994 & 105,2396 \\
Constant p-value & $<0,00001$ & $<0,00001$ & $<0,00001$ & $<0,00001$ & $<0,00001$ & $<0,00001$ \\
Regressor & 0,0045 & 0,0048 & 0,0029 & $-0,0039$ & $-0,0038$ & $-0,0003$ \\
Regressor standard error & 0,0108 & 0,0112 & 0,0115 & 0,0116 & 0,0115 & 0,0116 \\
Regressor t-ratio & 0,4157 & 0,4249 & 0,2546 & $-0,3321$ & $-0,3289$ & $-0,0291$ \\
Regressor p-value & 0,6779 & 0,6712 & 0,7992 & 0,7401 & 0,7425 & 0,9768 \\
Mean dependent var & 9,7847 & 9,7972 & 9,8130 & 9,8306 & 9,8448 & 9,8613 \\
Sum squared resid & 66,9822 & 62,8492 & 58,2221 & 53,4588 & 50,0857 & 46,3288 \\
Log-likelihood & $-205,832$ & $-193,541$ & $-179,754$ & $-165,570$ & $-155,099$ & $-143,702$ \\
Schwarz criterion & 423,2991 & 398,6125 & 370,9154 & 342,4167 & 321,3416 & 298,4146 \\
S. D. dependent var & 0,4432 & 0,4399 & 0,4361 & 0,4322 & 0,4322 & 0,4286 \\
S. E. of regression & 0,4472 & 0,4446 & 0,4413 & 0,4369 & 0,4372 & 0,4349 \\
Akaike criterion & 415,6649 & 391,0821 & 363,5079 & 335,1400 & 314,1973 & 291,4040 \\
Hannan-Quinn & 418,7081 & 394,0895 & 366,4724 & 338,0584 & 317,0684 & 294,2268 \\
\hline
\end{tabular}

Forrás: saját számítás.

F4. táblázat: Részletes regressziós eredmények a súlyozott hálózati kapcsolatok alapján számolt skálafüggetlenségi mutató mint magyarázóváltozó esetén Detailed panel regression results in the case of scalefree exponent calculated from weighted network

\begin{tabular}{l|rrrrrr}
\hline \multicolumn{1}{c|}{ log_SCALE_W } & \multicolumn{1}{c}{ lag0 } & \multicolumn{1}{c}{ lag1 } & \multicolumn{1}{c}{ lag2 } & \multicolumn{1}{c}{ lag3 } & \multicolumn{1}{c}{ lag4 } & \multicolumn{1}{c}{ lag5 } \\
\hline Constant & 9,4374 & 9,5016 & 9,5169 & 9,5549 & 9,5634 & 9,5800 \\
Constant standard error & 0,0955 & 0,0951 & 0,0956 & 0,0958 & 0,0969 & 0,0958 \\
Constant t-ratio & 98,8140 & 99,8933 & 99,5234 & 99,7096 & 98,6431 & 100,0041 \\
Constant p-value & $<0,00001$ & $<0,00001$ & $<0,00001$ & $<0,00001$ & $<0,00001$ & $<0,00001$ \\
Regressor & 0,1160 & 0,1014 & 0,1007 & 0,0895 & 0,0948 & 0,0964 \\
Regressor standard error & 0,0131 & 0,0132 & 0,0129 & 0,0124 & 0,0121 & 0,0124 \\
Regressor t-ratio & 8,8555 & 7,6511 & 7,8002 & 7,2339 & 7,8649 & 7,7989 \\
Regressor p-value & $<0,00001$ & $<0,00001$ & $<0,00001$ & $<0,00001$ & $<0,00001$ & $<0,00001$ \\
Mean dependent var & 9,7165 & 9,7328 & 9,7486 & 9,7658 & 9,7837 & 9,7999 \\
Sum squared resid & 59,0014 & 55,8740 & 52,4653 & 49,5846 & 45,9426 & 42,4980 \\
Log-likelihood & $-181,423$ & $-172,209$ & $-162,046$ & $-153,329$ & $-142,592$ & $-132,376$ \\
Schwarz criterion & 374,2341 & 355,7238 & 335,2958 & 317,7640 & 296,1856 & 275,6590 \\
S. D. dependent var & 0,4736 & 0,4703 & 0,4661 & 0,4605 & 0,4547 & 0,4502 \\
S. E. of regression & 0,4465 & 0,4436 & 0,4408 & 0,4392 & 0,4339 & 0,4280 \\
Akaike criterion & 366,8466 & 348,4188 & 328,0915 & 310,6581 & 289,1831 & 268,7569 \\
Hannan-Quinn & 369,8041 & 351,3472 & 330,9841 & 313,5154 & 292,0030 & 271,5402 \\
\hline
\end{tabular}

Forrás: saját számítás. 


\section{Irodalom}

Aghion, P., Howitt, P. (1992): A Model of Growth Through Creative Destruction. Econometrica, 2., 323-351.

Almeida, P., Kogut, B. (1999): Localization of knowledge and the mobility of engineers. Management Science, 7., 905-917.

Anselin, L., Varga, A., Acs, Z. (1997): Local Geographic Spillovers between University Research and High Technology Innovations. Journal of Urban Economics, 3., 422-448.

Audretsch, D. B., Feldman, M. P. (1996): R\&D Spillovers and the Geography of Innovation and Production. American Economic Review, 4., 253-273.

Balconi, M., Breschi, S., Lissoni, F. (2004): Networks of inventors and the role of academia: An exploration of Italian Patent data. Research Policy, 1., 127-145.

Barabási, A-L. (2002): Behálózva. A hálózatok új tudománya. Hogyan kapcsolódik minden egymáshoz és mit jelent ez a tudományban, az üzleti és a mindennapi életben. Magyar Könyvklub, Budapest

Barabási, A-L., Albert R. (1999): Emergence of scaling in random networks. Science, 5439. 509-512.

Barabási, A-L., Albert, R., Jeong, H. (2000): Scale-free characteristics of random networks: The topology of the world wide web. Physica A, 69-77.

Bollobás, B. (2001): Random Graphs. Cambridge University Press, Cambridge, UK

Breschi, S., Lissoni, F. (2003): Mobility and social networks: localised knowledge spillovers revisited. CESPRI, Working Paper 142.

Callois, J. M., Angeon V. (2004): On the role of social capital on local economic development: an econometric investigation on rural employment areas in France. In: 78th Conference of Agricultural Economics Society. Agricultural Economics Society, Imperila College, London, 27.

Cantner, U., Graf, H. (2006): The Network of Innovators in Jena: An Application of Social Network Analysis. Research Policy, 4. 463-480.

Carayol, N., Roux, P. (2009): Knowledge flows and the geography of networks: A strategic model of small world formation. Journal of Economic Behavior \& Organization, 2., 414-427.

Chakrabarti, A. K., Dror, I., Eakabuse, N. (1993): Interorganizational Transfer of Knowledge. An Analysis of Patent Citations of a Defense Firm. IEEE T. Eng. Manage, 40., 91-94.

Chen, C. M., Hicks, D. (2004): Tracing knowledge diffusion. Scientometrics, 2., 199-211.

Cooke, P. (2001): Regional Innovation Systems, Clusters, and the Knowledge Economy. Industrial and Corporate Change, 4., 945-974.

Cooke, P., Gomez Uranga, M., Etxebarria, G. (1997): Regional Innovation Systems: Institutional and Organisational Dimensions. Research Policy, 4-5., 475-491.

Cowan, R. (2005): Network models of innovation and knowledge diffusion. In: Breschi S., Malerba F. (eds.): Clusters, Networks and Innovation. Oxford University Press, Oxford, 29-53.

Cowan, R., Jonard, N. (2004): Network structure and the diffusion of knowledge. Journal of Economic Dynamics and Control, 8., 1557-1575.

Csermely P. (2005): A rejtett hálózatok ereje. Vince Kiadó, Budapest

Ejermo, O., Karlsson, C. (2004): Spatial Inventor Networks As Studied by Patent Coinventorship. Working Paper Series in Economics and Institutions of Innovation 17, Royal Institute of Technology, CESIS - Centre of Excellence for Science and Innovation Studies

Erdős, P., Rényi, A. (1959): On Random Graphs I. In Publ. Math. Debrecen, 6, 290-297.

Feldman, M. P. (1994): The Geography of Innovation. Kluwer Academic Publisher, Boston

Granovetter, M. (1983): The Strength of Weak Ties: A Network Theory Revisited. Sociological Theory, 1., 201-233.

Granovetter, M. (1973): The Strength of Weak Ties. American Journal of Sociology, 6., 1360-1380.

Gress, B., (2010): Properties of the USPTO patent citation network: 1963-2002. World Patent Information, 1., 3-21.

Griliches, Z. (1990): Patent statistics as economic indicators: a survey. Journal of Economic Literature, 4., 1661-1707.

Grossman, G. M., Helpman, E. (1994): Endogenous Innovation in the Theory of Growth. Journal of Economic Perpectives, 8., 23-44. 
Heston, A., Summers, R., Aten, B. (2009): Penn World Table Version 6.3. Center for International Comparisons of Production, Income and Prices at the University of Pennsylvania

Jaffe, A. B. (1989): Real Effects of Academic Research. American Economic Review, 5., 957-970.

Jaffe, A. B., Trajtenberg, M. (2002): Patents, Citations and Innovations: A Window on the Knowledge Economy. MIT Press, Cambridge, MA

Johansson, B., Forslund, U. (2008): The analysis of location, co-location and urbanization economies. In: Karlsson (ed.): Handbook of Research on Cluster Theory, Edward Elgar, UK

Karinthy F. (1929): Minden másképpen van. Ötvenkét vasárnap. Athenaeum, Irodalmi és Nyomdai Rt., Budapest

Karki, M. M. (1997): Patent citation analysis: a policy analysis tool. World Patent Inf, 19., 269-272.

Li, X., Chen, H., Huang, Z., Roco, M. (2007): Patent citation network in nanotechnology (1976-2004). Journal of Nanoparticle Research, 3., 337-352.

Lundvall, B. A. (ed.) (1992): National systems of innovation: Towards a theory of innovation and interactive learning. Pinter, London

Maggioni M.A., Uberti T.E. (2005): International networks of knowledge flows: an econometric analysis. Papers on Economics and Evolution, Max Planck Institute of Economics, Evolutionary Economics Group. 2005-19. szám

Maggioni, M. A., Uberti, T. E., Usai, S. (2011): Treating patent as relational data: Knowledge transfers and spillovers across Italian provinces. Industry and Innovation, 1., 39-67.

OECD (2009): REGPAT Database, October 2009.

Oppenheim, C. (2000): Do Patent Citations Count? In: Cromin B., Atkins H.B (eds.): The Web of knowledge. Information Today Inc., Medford, 405-432.

Romer, P. (1990): Endogenous Technological Change. Journal of Political Economy, 5., S71-S102

Sebestyén T. (2011): Hálózatelemzés a tudástranszferek vizsgálatában. Régiók közötti tudáshálózatok struktúrájának alakulása Európában. Statisztikai Szemle, 6., 667-697.

Sebestyén T., Parag A., Kruzslicz F. (2011): A feltalálói kapcsolatok szerepe a high-tech szektorban. Sokféleség és specializáció a hálózatok tükrében. Tér és Társadalom, 3., 79-99.

Singh, J. (2003): Social Networks as Drivers of Knowledge Diffusion. Harvard University mimeao. Available at SSRN DOI: 10.2139/ssrn.431872.

Solow, R. M. (1957): Technical Change and the Aggregate Production Function. Review of Economics and Statistics, 3., 312-320.

Travers, J., Milgram, S. (1969): An Experimental Study of the Small World Problem. Sociometry, 4., 425-443.

Watts, D. J., Strogatz, S. H. (1998): Collective dynamics of 'small-world' networks. Nature, 393. 409-442.

Zucker, L., Darby, M., Armstrong J. (1994): Intellectual capital and the firm: The technology of geographically localized knowledge spillovers. NBER Working Paper Series, Working Paper no. 4946. 


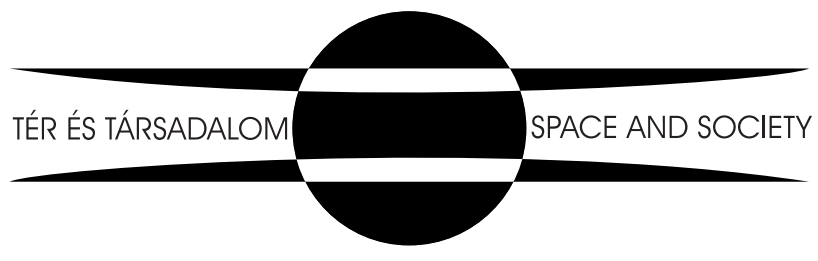

